\title{
Culture beyond borders: the amazigh past of the Canary Islands
}

\begin{abstract}
The Amazigh people from North Africa settled in the Canarian Archipelago at the beginnings of the $1^{\text {st }}$ millennium $\mathrm{BC}$ and developed a culture on the islands that can be linked to native North African societies and magical-religious practices associated with the religions of the ancient Amazigh. Nevertheless, the research developed during the $19^{\text {th }}$ and the beginnings of the $20^{\text {th }}$ centuries underestimated the African roots of the Canarian past. This paper analysis the archaeological evidences that reinforce the African roots of the Canarian indigenous people and the theoretical and political reasons that help to understand how the colonial past has played a crucial role in the making of the image of the Canarian natives.
\end{abstract}

Keywords: prehistoric archaeology, africa, canary islands, amazigh, human colonization, colonialism, heritage
Volume I Issue 6 - 2017

\author{
Farrujia de la Rosa AJ \\ Sociedad Española de Historia de la Arqueología, History of \\ Archaeology Research Network, UK
}

\begin{abstract}
Correspondence: José Farrujia de la Rosa, Sociedad Española de Historia de la Arqueología, History of Archaeology Research Network, UK, Email afarruji@hotmail.com
\end{abstract}

Received: August 29, 2017 | Published: October 16, 2017

\section{Introduction}

The Canarian indigenous people is the name given to the early inhabitants of the Canary Islands, an archipelago located on the Atlantic ocean, just 100 kilometres (62 miles) off the Southern cosat of Morocco and integrated by seven islands (from West to East: El Hierro, La Palma, La Gomera, Tenerife, Gran Canaria, Fuerteventura and Lanzarote). Regarding the origins of this population, an according to archaeological research, the Imazighen (Berbers) from North Africa settled in the Canarian Archipelago at the beginning of the 1st millennium $\mathrm{BC}$ and developed a culture on the islands that can be linked to native North African societies and magical-religious practices associated with the religions of the ancient Amazigh (singular word for Imazighen). ${ }^{1}$

\section{Materials and methods}

The Canarian indigenous people lived mainly in natural caves (and to a lesser extent in man-made caves cut into rocks), usually near the coast, $300-500 \mathrm{~m}$ above sea level. These caves were sometimes isolated but more commonly formed settlements, with burial caves nearby. Gran Canaria is the only island where settlements with stone houses forming important urban concentrations can be found, although isolated houses have also been documented. In terms of subsistence, animal husbandry was the main means of support for the indigenous societies in the different islands, with the exception of Gran Canaria, where agriculture was more developed, including both dry and irrigated farming. The herds basically consisted of goats and sheep and, to a lesser extent, pigs. Gathering plants and fishing also provided significant food resources.

Ceramics are the utensils most commonly found in archaeological excavations and also the most widely studied, due to the possibilities they offer, on the basis of a cultural-historical approach (which still prevails amongst Canarian archaeologists), for establishing timelines, food consumption patterns, stylistic trends, etc. In the Canary Islands they are typically varied, with each island presenting both formal and decorative differences. The only common feature is that they were made without the use of a wheel, since the indigenous ceramics were hand-made, by forming the base first then gradually shaping the sides of the container using small cylinders of clay. Ceramic items were often decorated with indentations or incisions or polished, in particular in Gran Canaria, where painted decorations in shades of red, black and white were also common. The La Palma ceramics provide the best stratgraphic sequence, which has four phases, although the Gran Canaria ceramics are undoubtedly the most complex, due to the variety of shapes, handles and decorative features. They also reveal the clearest affinities with North African Amazigh ceramics. The shape of the Tenerife ceramics enables parallels to be drawn with those documented in Mauritania and in the central and southern Sahara regions.

The raw materials used in the lithic industry were obsidian and basalt and the most common tools were burins, borers, racloirs and scrapers. The most typical polished stone items were millstones, used to grind cereals. In terms of the bone industry, which was based mainly on ovicaprine bones, grainers and awls for use in leatherwork were common, as well as fish hooks. Antlers were also used to make tools for ploughing or were set in wood to be used as projectiles (spears). There was also an important wood industry, essentially represented by shepherd's crooks, combs, shields, containers and doors for manmade caves and houses.

The majority of the plant fibres used by the Canarian indigenous people for clothing and basket-making came from rushes (Holoschoenus vulgaris), which were used to make mats, baskets, bags and shrouds, as well as garments, which were also manufactured from goatskin. In terms of social and political organisation, there was a system of matrilineal descent in most of the islands, in which inheritance was passed on via the female line. Social status and wealth were hereditary and determined the individual's position in the social pyramid, which consisted of the king (known as the Guanarteme in Gran Canaria and Mencey in Tenerife), the relatives of the king, the lower "nobility", villeins, plebeians and finally executioners, butchers, embalmers and prisoners. ${ }^{2}$

With regard to faith, the Canarian indigenous people, like the North African Imazighen groups, worshipped two celestial divinities, the sun and the moon and sacred natural places such as particular mountains, rocks and caves. Their religion revolved around the need 
for rainwater, on which the pasture land and crops and therefore the food for the indigenous people and their livestock, depended. Religious offices were usually carried out by men, although in Gran Canaria and Fuerteventura these duties were performed by women. Some indigenous sites have been associated with this cult, such as the cave paintings in Gran Canaria whose interiors display painted geometric motifs, the cup and groove sites, consisting of small spherical depressions carved into the rock and linked by man-made channels which are related to the spilling of liquids (libations) and the sacrificial altars, built in stone and varying in shape although mainly circular, used to burn animals sacrificed as offerings to the gods. ${ }^{3}$

The world of death was also related to cultural practices. In the Canary Islands, burial sites are one of the most common finds, although they have been plundered continuously since the 18th century. The indigenous Canarians beloved that life continued in another form after death and therefore supplied the corpse with provisions (ceramics, food, awls, beads, rush bags, etc.). They laid the bodies to rest by placing them on beds of stone, vegetation, animal skins etc. to avoid physical contact with the earth. The most common method of laying out corpses was to place them supine inside natural caves or shelters. In Gran Canaria they were also placed in excavated caves or tombs. ${ }^{4}$

Indigenous funeral rituals also included mummification, which was reserved for members of the "nobility" (as a prestige practice) and has been documented primarily in Tenerife and Gran Canaria. In this sense and according to Abreu Galindo, ${ }^{5}$ in the isle of Gran Canaria, nobles and gentry were mummified and then deposited in burial caves. Also, as $\mathrm{Arco}^{4}$ has argued, the mummified remains studied in the Canary Islands present a size above average, an important level of leptosomia and they lived longer. These, in fact, are the main biological characteristics of the upper social strata. It is also relevant the following aspect: mummification is represented by a small percentage compared to non mummification and this is indicative of the existence of social differences expressed at the time of burial.

Further evidence of the North African origins of the indigenous Canary Island populations can be seen in the rock engravings, featuring a script classified as Lybico-Berber which shows clear affinities with scripts recorded in Libya and Algeria. ${ }^{6}$ Moreover, from a genetic point of view, the closest counterparts to $55 \%$ of the descendants of the indigenous populations are found in the Maghreb. ${ }^{7}$

\section{Results and discussion}

Regarding the early colonisation of the islands, we are still far from being able to form a final opinion on the situation regarding the Archipelago as a whole, since the extent of the research differs widely from island to island. The present-day situation is unpromising since, although research in recent decades has consolidated the CanarianAfrican relationship, it is clear that there is still no consensus in terms of origins (how did the islands become populated and colonised? How did the first settlers arrive?). Nevertheless, an examination of LybicoBerber inscription and radiocarbon dates available from some sites on the islands indicate that the Canary Islands were divided into two geographically overlapping areas of Amazigh influence in different times:

i. An archaic Amazigh culture in the 6th century BC, including El Hierro, Tenerife, Gran Canaria, La Palma and La Gomera.

ii. A Romanised Amazigh culture dating from the time of Augustus and Juba II, including Lanzarote, Fuerteventura, Gran Canaria, El Hierro and Tenerife. ${ }^{2}$

On the basis of current research, it is possible to refer to the existence of relations between some islands during the indigenous period (Tenerife-La Gomera, or Lanzarote-Fuerteventura-Gran Canaria), since certain aspects of the material culture would appear to indicate this. However, some cultural features in certain islands are not found in others since, despite the fact that they share the same base, the indigenous island cultures developed in isolation, with very little contact with the exterior. Given this, the poor quality of the ceramics, except in the case of Gran Canaria, leads to the conclusion that later contributions were rare, indicating cultural isolation until the time when the islands were rediscovered and conquered by the Europeans in the 14 th century. ${ }^{8}$

The entire indigenous culture, which had existed in the Canary Islands since the beginnings of the first millennium $\mathrm{BC}$, began to disappear irreversibly following the conquest and colonisation of the Archipelago which began in the Late Middle Ages. It should be noted that the indigenous Canarian culture can only be explained by a continental-African ethno genesis which is inseparable from the culture of certain ethnic Amazigh groups that lived approximately 2000 years ago. The culture developed in the Canarian Archipelago by Imazighen societies was clearly influenced by insular isolation and adaptation to the island environment under conditions which meant that they were virtually cut off from contact with the African continent and other ethnic Amazigh groups. This has made the indigenous archaeology of the Canary Islands an extraordinary, marginal and almost unclassifiable historical example of Amazigh or (North) African culture. In other words, the indigenous Canarian universe was unarguably Amazigh, although from the point of view of "positive culture" it is a unique case and an extraordinary product of involution (due to isolation) and adaptation to an island environment. The archaeological evidence and findings (ceramics, rock inscriptions, etc) and anthropological/genetical type (DNA) are indisputable. However, there are many gaps in our understanding of the circumstances in which the first settlers arrived in the Canary Islands. We still do not know how or why the North African Amazigh landed in the Canary Islands in the first millennium BC, although the early colonisation of the islands has recently been related to Phoenician-Punic influence in the Atlantic. ${ }^{2,9}$

\section{The gradual disappearance of the amazigh substrate}

As a result of the rediscovery, conquest and colonisation of the Canary Islands, the legacy of the individual communities that inhabited the different islands in the Archipelago up to the time of the European colonisation, began to disappear irreversibly as a direct result of the gradual disappearance of the indigenous Canarian societies. In the case of the Canary Islands, unlike the situation in the American continent or in Australia, there is no historical continuity between the indigenous, pre-colonial and post-colonial societies, since the conquest and subsequent colonisation of the Canary Islands by the Crown of Castile led to the gradual physical destruction of almost the entire indigenous society. In fact, the Canarian economy became characterised essentially by a model based on agricultural development, which, in turn, formed part of the Atlantic and international economy. This led to the development of a dependent and peripheral economy from the beginning of the 16th century and a colonial society composed of a ruling group (the aristocracy, clergy and merchants i.e. those who held political positions and controlled 
the economy) and the majority whom they ruled (labourers, those marginalised for religious reasons and slaves, including the Canarian indigenous people). ${ }^{10}$

In the case of the Canary Islands therefore, the concept of "indigenous" implies clear temporal connotations: it refers to the populations present on the islands since the time of the first settlements in the Archipelago (first millennium BC) until its rediscovery in the 14th century by Europeans. In fact, at the end of the 17th century, as a consequence of the gradual disappearance of the indigenous Canarian people and their culture, their legacy began to be viewed from a more archaeological than ethno-historical perspective. Earlier in the 15th century, the indigenous Canarian populations were still thriving and since they were not fossils, were not considered from a pre-scientific archaeological perspective. ${ }^{11}$

The rediscovery of the Canary Islands by the Europeans therefore led to the gradual disappearance of the indigenous settlements, the elimination of material items from the indigenous culture, the appropriation of indigenous areas, which were occupied by the new settlers and by the emerging colonial society and the imposition of ways of life and systems of social organisation and production governed by a western-style world view, values and regulatory mechanisms that were alien to the indigenous Canarian world. Over time, the arrival in the Archipelago of an imperialist archaeology, developed during the $19^{\text {th }}$ century and a good part of the $20^{\text {th }}$ century would help perpetuate the western, European interpretation of the indigenous Canarian past. ${ }^{12}$ This scenario clearly contrasts with the North African context, in which the Imazighen, the indigenous populations of the area, have maintained a constant presence since ancient times. ${ }^{13}$

\section{The remaking of the canarian indigenous past}

The imperialist archaeology in the Canary Islands involved the creation of specific versions of the past history of the Archipelago, all of which are completely different from each other and sometimes totally contradictory, whilst all tending to justify the social order established in the particular period in which they are produced. After the origins of archaeology in the Canary Islands (1868) and the development of the evolutionist theories, the indigenous Canarian population was linked to European, specifically French, prehistory. According to Canarian researchers, who studied in France, the Canarian indigenous people were the descendants of the Celts, of the Cro-Magnon race also documented in the Canary Islands. ${ }^{11}$ Cro-Magnon race contributed towards defending French imperialist interests in Africa and the Canary Islands. Reflecting the ethnocentric world view of the time, the expansion of the Cro-Magnon race beyond French territory implied that all the areas occupied by the said Quaternary race would have been populated in ancient times by the ancestors of the Gallic nation. Also, in applying external criteria to the Canary Islands, indigenous Canarian cultures were treated as if they shared the same evolutionary development as other parts of Europe. In this sense, the cultural evolutionist models simplified the indigenous Canarian societies, as they did other past societies. ${ }^{14}$

Later on, during Franco's dictatorship, the "indigenous Canarian of European origins" from the end of the 19th century became the "indigenous Canarian of Hispanic origins" with Ibero-Saharan and Ibero-Mauritanian roots during the Franco period. The relationship established between these substratum and the Spanish Sahara, enabled to endorse the nationalist politics of the Franco regime since the first settlers in the Iberian Peninsula, the Canary Islands and the Spanish colony in Africa would have shared the same racial and cultural roots in ancient times. ${ }^{11}$

Parallel to this, archaeological heritage management underwent certain changes that nevertheless failed to improve the organisation, understanding, protection and dissemination of the indigenous heritage. The nineteenth-century private initiatives, represented by museums and offices run by bourgeois Canarian intellectuals, were replaced in the 20th century by the intervention of the Franco government, involving a centralised management, the development of fieldwork, a greater number of excavations and the reinforcement of a colonial discourse. Canarian archaeological evidence was analysed on the basis of this colonialist discourse and this knowledge was essentially disseminated via the museums. The mummies and indigenous artefacts (basically ceramics and lithic and bone tools) displayed in glass cases and interpreted from this point of view helped reinforce a simplistic, "prehistoric" reading of indigenous Canarian societies amongst the general public. In other words, the Spanish government imposed its particular vision of heritage, set up an institutional framework and organised conservation practices in the Canary Islands. An unequal power relationship was therefore the starting point for any consideration of the Canarian heritage on the part of the Franco regime. The archaeology of the Canary Islands was perceived through the "filter" of the knowledge produced by the "new colonisers". ${ }^{11}$

\section{Conclusion}

Nowadays, the archaeology of the Canary Islands shares three of the most common characteristics of social histories of archaeology worldwide, as defined by authors such as Hodder, ${ }^{15}$ Trigger, ${ }^{16}$ Lozny ${ }^{17}$

a. a culture-history approach as the key methodology and basis for locally generated theories (with a strong nationalistic flavour)

b. the use of archaeology for political (nationalistic) goals

c. a tendency to relate archaeological research topics to existing political conditions and demands.

In this sense, European colonial discourse that influenced archaeology in other indigenous contexts (Australia, Canada, Africa, etc.) is also evident in Canary Islands. As Ireland ${ }^{18}$ has pointed out, indigenous and non-indigenous communities are all engaged in the active 'use' of the colonial archaeological heritage as much as any other form of tangible or intangible heritage.

The social factors involved in Canarian archaeology are Spanish. It may be said that we now have new, postmodern empires without colonies, endowed with their own knowledge-power strategies. In this sense, according to Ireland, ${ }^{18}$ the role of heritage has been closely linked to the construction and reinforcement of national and ethnic identities and, in the postcolonial world, to projects which still legitimise colonial occupation. The Canary Islands is not a Spanish colony, but one of the Autonomous Communities that make up the country. At the same time, however, it is a geographical area politically controlled by a distant country, a vestige of a past empire, a national territory next to the African continent. In other words, they are an overseas territory like the French DOM (Guadeloupe, Guyana, Martinique and Reunion) and are considered an Outermost Region (OMR) by the European Union. The actual geostrategic location of the Canarian Archipelago in the Atlantic has helped to historically reinforce the concept of the islands as a Spanish overseas possession 
and a strategic enclave in relation to the neighbouring continent of Africa. These factors and the almost total lack of renewal of theory within Canarian archaeology help to explain, to a great extent, why the colonial discourse still lives on archaeology in the Canary Islands and still underestimates the Amazigh past of the whole Archipelago. ${ }^{19}$

\section{Acknowledgements}

None.

\section{Conflict of interest}

Author declares there is no conflict of interest in publishing the article.

\section{References}

1. Hachid M. Les premiers berberes: entre Mediterranee, Tassili et Nil Edisud, France; 2000.

2. Farrujia RAJ, Pichler W, Rodrigue A, et al. The Lybico-Berber and Latino-Canarian Scripts and the colonization of the Canary Islands. African Archaeological Review. 2010;27(1):13-41.

3. Mederos MA, Escribano CG. Los aborígenes y la prehistoria de Canarias. Centro de la Cultura Popular Canaria. Spain; 2002. p. 184.

4. Aguilar AMC. De nuevo, el enterramiento canario prehispánico. Tabona. 1992,1993;8(1):59-76.

5. Galindo AJ. Introducción y notas a cargo de Alejandro Cioranescu. Historia de la conquista de las siete islas de Canaria, Goya Ediciones, Spain; 1977.

6. Gaspar TA, Jiménez GJ, Allen J. Las manifestaciones artísticas prehispánicas y su huella. Historia Cultural del Arte en Canarias, vol I Gobierno de Canarias, Spain; 2008. p. 238.

7. Fregel R, Gomes V, Gusmão L, et al. Demographic history of Canary Islands male gene-pool: replacement of native lineages by European, BMC Evol Biol. 2009;9:181.
8. Gaspar TA. Los libio-bereberes que poblaron las Islas Canarias en la Antigüedad. In: Tejera GA, editor. Canarias y el África Antigua, Centro de la Cultura Popular Canaria. Spain; 2006. p. 81-105.

9. Aguilar AMC, Aguilar AM, Mateo BC, et al. Un taller romano de púrpura en los límites de la Ecúmene. Cabildo Insular de Tenerife. Spain; 2017.

10. Hernández MA. Canarias, 1800-2000. La singularidad de la historia económica isleña. Historia Contemporánea. 2011;42:225-259.

11. Farrujia RAJ. Colonialism, amazighity and heritage management in the Canary Islands. Archaeology of the margins. Springer Briefs in Archaeology, USA; 2014.

12. Farrujia RAJ. Imperialist archaeology in the Canary Islands. French and German studies on prehistoric colonization at the end of the 19th century, International Archaeological Reports since. Bar publishing, UK; 2005. p. 150 .

13. Tilmatine M. Los estudios amaziges. Bibliografía temática. Ediciones Bellaterra, Spain; 2008. p. 222.

14. Johnson M. An introduction. Archaeological theory 2nd ed. WileyBlackwell, UK; 2010.

15. Hodder I. Archaeological Theory Toda, 2nd ed. Polity Press, USA; 2001.

16. Trigger B. A History of Archaeological Thought 2nd ed. Cambridge University Press, USA; 2006. p. 710.

17. Lozny LR. A Sociological View of the Science of the Past. Comparative Archaeologies, Springer, Germany; 2011.

18. Ireland T. Excavating Globalization from the Ruins of Colonialism: Archaeological Heritage Management Responses to Cultural Change. ICOMOS Scientific Symposium Changing World, Ireland; 2010.

19. Peña AP. Excavaciones arqueológicas en el sitio de Buenavista (Lanzarote): Nuevos datos para el estudio de la colonización protohistórica del archipiélago canario. Gerión. 2011;29(1):59-82. 